\title{
Assessment of Environmental Safety Related Radioactivity Exposure in Zircon Sand
}

\author{
Diah Dwiana Lestiani, Syukria Kurniawati, Indah Kusmartini, Natalia Adventini, \\ Woro Yatu Niken Syahfitri, dan Muhayatun Santoso \\ Center for Applied Nuclear Science and Technology, National Nuclear Energy Agency, BATAN \\ Jln. Tamansari 71, Bandung, Email: diahdwi@batan.go.id
}

(Diterima tanggal 25 Februari 2019, Disetujui tanggal 27 Mei 2019)

\begin{abstract}
Zircon sand is one of major sources that are responsible for naturally occurring radionuclides in the earth's crust such as ${ }^{238} \mathrm{U}$ and ${ }^{232} \mathrm{Th}$. The mining and processing of zircon sand are found in several places in Indonesia such as in Bangka Belitung, Borneo and Riau. These activities are potential to produce some radioactivity exposure to the occupational area and surrounding environment. Therefore, the assessment of the environmental safety related radioactivity exposure in zircon sands is needed to ensure the safety of the worker and public. In this study, the concentration of uranium and thorium in zircon sands collected from several sites in Borneo were determined and evaluated using instrumental neutron activation analysis (INAA). Samples were irradiated in rabbit system facility of G.A Siwabessy, Serpong reactor with neutron flux $\sim 10^{13} \mathrm{n} . \mathrm{cm}^{-2} . \mathrm{s}^{-1}$ for 15 minutes and 2 hours, and then counted with HPGe detector of gamma spectrometry. In order to assess the accuracy of the analysis, soil reference materials (RMs) were analyzed together with the samples. The results of reference material analysis showed a good agreement with the certificate value. The measurement results showed that the concentration of uranium and thorium varied widely depending on the sample origin. Uranium and thorium concentrations were $214.8 \pm 101.7$ and 209.9 $\pm 169.0 \mathrm{mg} / \mathrm{kg}$, respectively. These values were equivalent to $2654 \pm 1258 \mathrm{~Bq} / \mathrm{kg}$ for ${ }^{238} \mathrm{U}$ and $848 \pm 683 \mathrm{~Bq} / \mathrm{kg}$ for ${ }^{232} \mathrm{Th}$, respectively. The results showed the annual equivalent dose average of $2.1 \pm 1.04 \mathrm{mSv} / \mathrm{year}$, which above the dose limit of the publis $(1 \mathrm{mSv} /$ year) and varies between 0.4 and $5.3 \mathrm{mSv} /$ year. The characterization of zircon sands using INAA showed reliable results and could be utilized to assess the level of radioactive materials content in the zircon sands related to government regulation on zircon sand radioactive exposure, as well as the precaution to reduce needless exposure of the workers and public.
\end{abstract}

Keywords: NORM, TENORM, zircon sands, thorium, uranium, INAA

\section{INTRODUCTION}

The exposure of human beings to ionizing radiation from natural sources is a continuing and inescapable feature of life on the earth. According to the United Nations Scientific Committee on Effect of Atomic Radiation report (UNSCEAR 2008), the greatest contributions to human exposure is from natural background radiation, and worldwide average annual effective dose per capita is $2.4 \mathrm{mSv}[1,2]$. Exploitation and processing of natural materials, minerals and other resources often increases naturally occurring radioactive concentrations material (NORM) in products, by-products, residues or waste arising from the industrial process. This process is often called
TENORM (Technology Enhanced Natural Radioactive Materials) which has the potential to increase the radiation exposure to the workers and public $[3,4]$. Occupational exposure doses to workers are mostly measured, while the exposure doses to the public are usually assessed by indirect methods, typically using measurements performed in the environment or of environmental samples, modelling various exposure scenarios and employing data on population $[1,5]$.

Several mining activities that have a potential high risk of radiation exposure have been regulated and make a big concern for regulation 
body. Apart from uranium mining and milling, applications using natural radionuclides and, more recently, zircon industry and processing activities from raw materials zircon sand have generally not been fully evaluated from the perspective of public exposure [6]. Therefore, the assessment of the environmental safety related radioactivity exposure in zircon sands is needed to ensure the safety of the worker and public. In this study, the assessment of environmental safety through determination of radiation exposure and absorbed gamma dose rate as well as the external annual effective dose rate from zircon sands are carried out using neutron activation analysis.

Zircon sand is one of ore materials potential in Indonesia which one of its inventories located in several places i.e. Bangka Belitung, Borneo and Riau. In general, zircon sand $\left(\mathrm{ZrSiO}_{4}\right)$ contains other valuable mineral such as mineral rutile $\left(\mathrm{TiO}_{2}\right)$ and ilmenite $\left(\mathrm{FeTiO}_{2}\right)$, aluminium oxide, rare earth elements and naturally occurring radioactive materials (NORM) such as $\mathrm{U}_{3} \mathrm{O}_{8}$ and $\mathrm{ThO}_{2}$ $[4,6]$. Characterization of zircon sands will enable and provide valuable information about the natural radioactivity elements to assess and evaluate the environmental safety related radiation exposure from zircon sands. A suitable, well established method of determination of radioactivity is using gamma spectrometry $[7,8]$. Other approaches using analysis method such as instrumental neutron activation analysis and particles induced X-ray emission have been conducted $[9,10]$. Nuclear analytical techniques neutron activation analysis is one of widely used methods for characterization of geological samples such as zircon sands. Instrumental neutron activation analysis (INAA) is a sensitive analytical technique useful for performing both qualitative and quantitative multi-element analysis of major, minor, and trace elements in samples from almost every field of scientific or technical interest [11]. It is one of the more mature analytical methods currently in uses and yet remains highly competitive with others in term of accuracy, detection limits and multi elemental capabilities.

\section{EXPERIMENTAL}

\section{Materials and equipment}

For this study, the materials used are vial polyethylene $0.3 \mathrm{~mL}$, standard solution of uranium and thorium, mixed standard of radioactivity for detector calibration, and the equipment are flask, pipettes, semi micro balance and HPGe detector.

\section{Measurement of $U$ and Th using INAA}

Measurement using INAA was carried out in BATAN Bandung laboratory. INAA for products of neutron capture with medium halflives was used to determine uranium, while for long lived products was used to determine thorium [9]. A total of 26 samples of zircon sands were collected from the mining sites in Borneo, then samples were dried under the sun and homogenized for analysis. Duplicate 25 $\mathrm{mg}$ portions were prepared for determination of short-lived products and triplicate $25 \mathrm{mg}$ portions for long-lived INAA. The masses of each sample were recorded to \pm 0.01 mg using an analytical balance. Synthetic standard solutions were prepared from metals or compounds of known purity solution. For validation and to assess the accuracy of the analysis, control samples of standard reference 
materials SRM NIST 2711a Montana Soil, and International Atomic Energy Agency IAEA-Soil 7 were also analyzed in the same experimental conditions used in the sample analysis. Each sample, each RM and each standard were encapsulated in heat-sealed polyethylene vials prior to neutron irradiation. Samples were irradiated in rabbit system facility of G.A Siwabessy Serpong reactor of $15 \mathrm{MW}$ with neutron flux $\sim 10^{13} \mathrm{n} \cdot \mathrm{cm}^{-2} . \mathrm{s}^{-1}$. For determination of medium lived nuclides, each sample was irradiated for 15 minute together with standards and IAEA-RM, and then counted with HPGe detector of gamma spectrometry. The medium-lived assays were performed after decay times of 1-3 days. For INAA determination of longer-lived nuclides, samples, standards, control samples and IAEA RMs were placed into polyethylene irradiation containers and irradiated for 2 hours in the same facility in rabbit system facility of G.A Siwabessy Serpong reactor.

For determination long-lived nuclides were performed after approximately 2-4 weeks of decay, with each sample or element standard counted at a distance of $5-15 \mathrm{~cm}$ from the surface of gamma-ray germanium spectrometer. The measurement of $\mathrm{U}$ and $\mathrm{Th}$ were performed using $\mathrm{Np}$ and $\mathrm{Pa}$, since after some decay time the whole $\mathrm{U}$ and $\mathrm{Th}$ will decay as $\mathrm{Np}$ and $\mathrm{Pa}$ [9]. Neutron irradiation into the samples cause the radionuclide ${ }^{238} \mathrm{U}$ and ${ }^{232} \mathrm{Th}$ activated as follow:

$$
\begin{gathered}
{ }^{238} \mathrm{U}+n \rightarrow{ }^{239} \mathrm{U} \rightarrow{ }^{239} \mathrm{~Np} \\
{ }^{232} \mathrm{Th}+n \rightarrow{ }^{233} \mathrm{Th} \rightarrow{ }^{233} \mathrm{~Pa}
\end{gathered}
$$

Np was measured at $277.7 \mathrm{keV}$, while Pa was measured at $312 \mathrm{keV}$.

\section{Radiation hazard indices}

The mass concentrations of ${ }^{238} \mathrm{U}$ and ${ }^{232} \mathrm{Th}$ in the zircon sand can be converted into the activity concentrations assuming equilibrium exits in $U$ and Th decay series, based on the formula $[7,9]$ :

$$
A=\frac{C_{A} \cdot \lambda \cdot \dot{I} \cdot f_{a}}{W \cdot C}
$$

where $A$ is the specific activity of the radioisotope $(\mathrm{Bq} / \mathrm{kg}), C_{E}$ is the elemental concentration $(\mu \mathrm{g} / \mathrm{g}), N$ is Avogadro's number $\left(6.02 \times 10^{23}\right.$ atom $\left./ \mathrm{mol}\right)$ and $\lambda$ is decay constant $(s-1)$ of radionuclide, $f$ is the fractional atomic abundance of the radionuclide in nature $(\%$ or ppm), $W$ is the atomic mass $(\mathrm{kg} / \mathrm{mol})$ and $C$ is a constant (with value of 100 or $10^{6}$ ) that converts the ratio of the mass of the element to the mass of the sand into a percentage or parts per million (ppm). Activity levels are in Bq/ $\mathrm{kg}$ with the formula (1) one can calculate that $1 \mathrm{ppb}$ of ${ }^{238} \mathrm{U}$ and ${ }^{232} \mathrm{Th}$ corresponds to 12.34 and $4.05 \mathrm{~Bq} / \mathrm{kg}$, respectively $[12,13]$.

The absorbed dose rates due to gamma radiations in air at $1 \mathrm{~m}$ above the ground surface for the uniform distribution of the naturally occurring radionuclides $\left({ }^{226} \mathrm{Ra}\right.$ of U-series, ${ }^{232} \mathrm{Th}$ and ${ }^{40} \mathrm{~K}$ ) were calculated based on guidelines provided by UNSCEAR [1]. The conversion factors used to calculate the absorbed $\gamma$-dose rate $(D)$ in air per unit activity concentration in $\mathrm{Bq} / \mathrm{kg}$ (dry-weight) corresponds to $0.462 \mathrm{nGy} / \mathrm{h}$ for ${ }^{238} \mathrm{U}, 0.604$ $\mathrm{nGy} / \mathrm{h}$ for ${ }^{232} \mathrm{Th}$ and $0.0417 \mathrm{nGy} / \mathrm{h}$ for ${ }^{40} \mathrm{~K}$.

$$
\begin{gathered}
D(\mathrm{nGy} / \mathrm{h})=\left[0.462 A\left({ }^{238} \mathrm{U}\right)+0.604 A\left({ }^{232} \mathrm{Th}\right)\right. \\
\left.+0.0417 A\left({ }^{40} \mathrm{~K}\right)\right] \mathrm{nGy} / \mathrm{h}
\end{gathered}
$$


Table 1. Results of IAEA RM Soil and NIST 2711a

\begin{tabular}{rccc}
\hline Element & Analysis result $(\mathrm{mg} / \mathrm{kg})$ & $\begin{array}{c}\text { Certificate value } \\
(\mathrm{mg} / \mathrm{kg})\end{array}$ & Bias $(\%)$ \\
\hline $\begin{array}{c}\text { IAEA RM soil } \\
\text { Th }\end{array}$ & 8.18 & 8.2 & -0.2 \\
NIST 2711a & & & \\
Th & $15 \pm 0.2$ & $15 \pm 1$ & 0.0 \\
$\mathrm{U}$ & $3.07 \pm 0.66$ & $3.01 \pm 0.12$ & 2.0 \\
\hline
\end{tabular}

where $A\left({ }^{238} \mathrm{U}\right), A\left({ }^{232} \mathrm{Th}\right)$ and $A\left({ }^{40} \mathrm{~K}\right)$ are the activity concentrations of ${ }^{238} \mathrm{U},{ }^{232} \mathrm{Th}$ and ${ }^{40} \mathrm{~K}$, respectively.

\section{RESULT AND DISCUSSIONS}

Mass and radioactivity concentration of ${ }^{238} U$ and ${ }^{232}$ Th using INAA

The analytical result of reference materials and standard with its certificate values are presented in Table 1. The results obtained were in good agreement with the certificate values and it showed a good recovery and precision. The mass concentrations of uranium and thorium are shown in Figure 1, while the calculated activity levels in zircon sands are shown in Table 2. The results showed that

Table 2. Elemental and activity concentrations of radionuclides in the samples for mining sites

\begin{tabular}{ccc}
\hline & ${ }^{238} \mathrm{U}$ & ${ }^{232} \mathrm{Th}$ \\
\cline { 2 - 3 } Sample ID & Activity $(\mathrm{Bq} / \mathrm{kg})$ & Activity $(\mathrm{Bq} / \mathrm{kg})$ \\
\hline A1 & $2390.8 \pm 47.9$ & $617.9 \pm 11.3$ \\
A2 & $883.9 \pm 37.7$ & $598.8 \pm 4.3$ \\
A3 & $3294.3 \pm 39.1$ & $858.5 \pm 11.5$ \\
A4 & $2415.4 \pm 38.1$ & $380.1 \pm 10.7$ \\
A5 & $1531.4 \pm 62.4$ & $473.8 \pm 7.2$ \\
A6 & $6181.8 \pm 47.6$ & $2419.0 \pm 11.5$ \\
A7 & $2768.5 \pm 42.9$ & $756.9 \pm 11.1$ \\
A8 & $1033.1 \pm 54.6$ & $472.2 \pm 6.1$ \\
A9 & $3616.2 \pm 34.1$ & $1198.1 \pm 11.9$ \\
A10 & $1563.8 \pm 146.6$ & $2479.2 \pm 8.3$ \\
A11 & $4221.2 \pm 48.8$ & $402.8 \pm 10.9$ \\
A12 & $1133.6 \pm 73.5$ & $454.3 \pm 6.4$ \\
A13 & $2250.1 \pm 67.8$ & $544.1 \pm 10.8$ \\
A14 & $353.4 \pm 33.2$ & $238.1 \pm 9.5$ \\
A15 & $3721.2 \pm 52.7$ & $551.9 \pm 10.4$ \\
A16 & $2780.6 \pm 49.4$ & $79.9 \pm 3.1$ \\
A17 & $2675.8 \pm 49.6$ & $1525.2 \pm 11.9$ \\
A18 & $2915.4 \pm 52.8$ & $2165.2 \pm 12.6$ \\
A19 & $2228.7 \pm 46.2$ & $621.0 \pm 6.3$ \\
A20 & $2629.0 \pm 39.6$ & $932.1 \pm 6.4$ \\
A21 & $2927.2 \pm 43.2$ & $409.2 \pm 10.2$ \\
A22 & $4579.2 \pm 49.0$ & $1961.4 \pm 14.3$ \\
A23 & $3679.6 \pm 46.1$ & $373.7 \pm 11.8$ \\
A24 & $2730.4 \pm 47.4$ & $631.2 \pm 10.3$ \\
A25 & $1745.0 \pm 58.1$ & $234.4 \pm 6.0$ \\
A26 & $2671.0 \pm 58.0$ & $728.7 \pm 8.8$ \\
\hline
\end{tabular}




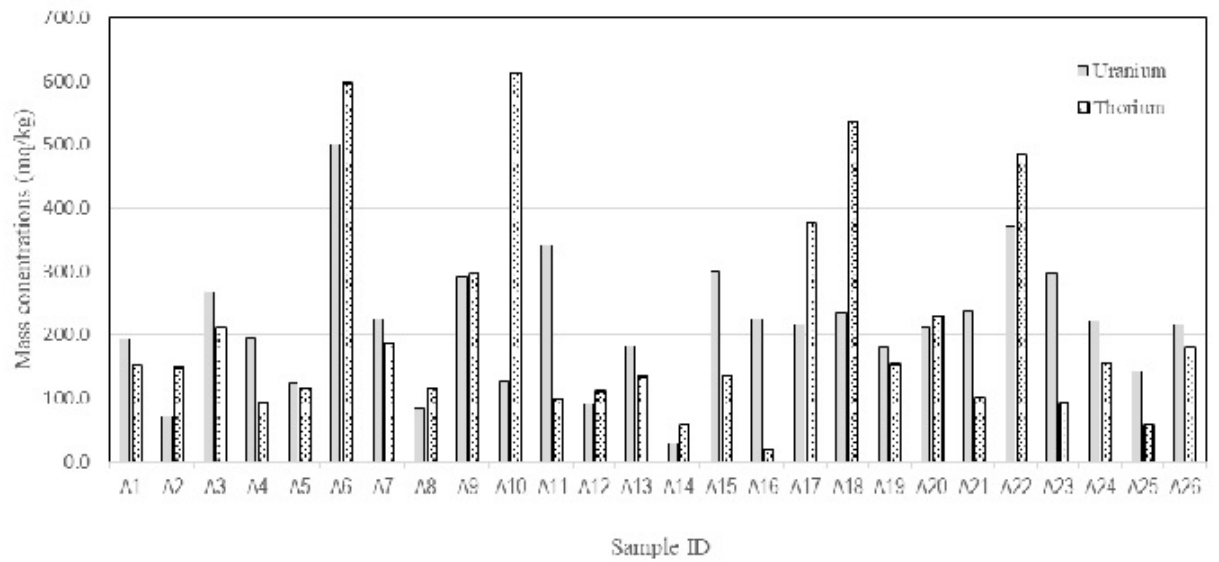

Figure 1. Mass concentration of $U$ and Th in zircon sands

these radionuclides were significantly present in all samples. The mass concentration of $U$ and Th were varied from 28.6 to $500.8 \mathrm{mg} / \mathrm{kg}$ and 19.7 to $612.1 \mathrm{mg} / \mathrm{kg}$, respectively. Most of the samples about $85 \%$ are higher than 100 $\mathrm{mg} / \mathrm{kg}$, only several samples content lower concentrations. The average concentrations of uranium and thorium concentrations were $214.8 \pm 101.7$ and $209.9 \pm 169.0 \mathrm{mg} / \mathrm{kg}$, respectively. These values were equivalent to $2654 \pm 1258 \mathrm{~Bq} / \mathrm{kg}$ for ${ }^{238} \mathrm{U}$ and $848 \pm 683 \mathrm{~Bq} /$ $\mathrm{kg}$ for ${ }^{232} \mathrm{Th}$, respectively.

Syarbaini et al reported the average and ranges of activity concentrations of ${ }^{238} \mathrm{U}$ and ${ }^{232} \mathrm{Th}$ in soil collected from Bangka and Belitung islands were higher than the common areas world average of soil. Bangka and Belitung islands are geologically contains higher concentrations of natural radionuclides than most other areas. The mean activity concentrations of ${ }^{238} \mathrm{U}$ and ${ }^{232} \mathrm{Th}$ were 72.3 and $203 \mathrm{Bg} / \mathrm{kg}$, respectively [14]. The current worldwide average values of ${ }^{238} \mathrm{U}$ and ${ }^{232} \mathrm{Th}$ are $37 \pm 4$ and $33 \pm 3 \mathrm{~Bq} / \mathrm{kg}$, respectively [1]. Obviously ${ }^{238} \mathrm{U}$ and ${ }^{232} \mathrm{Th}$ in zircon sand in this study are higher than the worldwide soils and Bangka Belitung soil.
As the results in Table 2, most of the zircon sand samples produced total activity of ${ }^{238} \mathrm{U}$ and ${ }^{232} \mathrm{Th}$ with magnitude of more than $1000 \mathrm{~Bq} / \mathrm{kg}$. The IAEA basic security standard proposed that the materials should be regulated if the materials containing radionuclides of natural origin at activity concentrations above $1 \mathrm{~Bq} / \mathrm{g}$ for radionuclides in the uranium and thorium decay series, and materials with radionuclides below $1 \mathrm{~Bq} / \mathrm{g}$ could become regulated due to the existence of total activity limit [6]. Since the uranium series activity concentrations in zircon exceed $1 \mathrm{~Bq} / \mathrm{g}$, regulatory consideration is needed for the handling of these minerals, as well as their disposal as a result of their use.

Uranium and thorium are primarily associated with heavy minerals such as monazite, zircon and allanite [16-20]. Righi et al analyzed zircon sands used in a refractory plant, and they reported the mean radioactivity concentrations of ${ }^{238} \mathrm{U}$ and ${ }^{232} \mathrm{Th}$ in raw material zircon sands were 490 and $420 \mathrm{~Bq} /$ $\mathrm{kg}$, respectively [18]. A review conducted by UNSCEAR on zircon sands reported the average activity concentrations are 3000 $\mathrm{Bq} / \mathrm{kg}$ for ${ }^{238} \mathrm{U}$ and $600 \mathrm{~Bq} / \mathrm{kg}$ for ${ }^{232} \mathrm{Th}$ [1]. Our results from this study were in similar 
Table 3. Activity concentrations of ${ }^{238} \mathrm{U}$ and ${ }^{232} \mathrm{Th}$ in zircon sands from several countries

\begin{tabular}{lcc}
\hline Samples & ${ }^{238} \mathrm{U}(\mathrm{Bq} / \mathrm{kg})$ & ${ }^{232} \mathrm{Th}(\mathrm{Bq} / \mathrm{kg})$ \\
\hline Zircon sand, India [8] & 3531 & 618 \\
Zircon sand, Orissa, India [12] & $3450 \pm 150$ & $1850 \pm 180$ \\
Zircon sand, Egypt [13] & $4910 \pm 160$ & $1195 \pm 48$ \\
Zircon sand, Australia [18] & $2400 \pm 200$ & $520 \pm 40$ \\
Zircon sand, South Africa [18] & $3200 \pm 300$ & $520 \pm 40$ \\
Zircon sand, Italy [18] & $2800 \pm 200$ & $590 \pm 30$ \\
Heavy sand, Kalatoli, Bangladesh [20] & $1651 \pm 133$ & $2625 \pm 96$ \\
Black sand, Egypt [13] & $260 \pm 25$ & $410 \pm 43$ \\
Monazite sand, Egypt [13] & $40580 \pm 1370$ & $182425 \pm 9870$ \\
Zircon sand, world average [1] & 3000 & 600 \\
Soil, world average [1] & 37 & 33 \\
Zircon sand, this study & $2654 \pm 1258$ & $848 \pm 683$ \\
\hline
\end{tabular}

level of magnitude with those reported by UNSCEAR and other authors (Table 3). But these values are higher than soil and black/ iron sand and lower than monazite sand.

\section{Absorbed gamma dose rates and estimated annual effective dose}

From the activity concentrations of ${ }^{238} \mathrm{U}$ and ${ }^{232} \mathrm{Th}$ in zircon sands, the absorbed gamma dose rates in air were calculated. Based on other study reported that ${ }^{40} \mathrm{~K}$ in zircon sand were less than $200 \mathrm{~Bq} / \mathrm{kg}$ [8], and using the conversion factor of 0.0417 in formula (2) for ${ }^{40} \mathrm{~K}$, we can calculate that ${ }^{40} \mathrm{~K}$ contributes less than one hundredth. By assuming that ${ }^{40} \mathrm{~K}$ contribution are less significant, the absorbed gamma dose rates in air from ${ }^{238} \mathrm{U}$ and ${ }^{232} \mathrm{Th}$ varied from 307 to $4317 \mathrm{nGy} /$ hour with average of $1738 \mathrm{nGy} /$ hour. The conversion coefficient from absorbed gamma dose rate in air to effective dose $(0.7 \mathrm{~Sv} / \mathrm{Gy})$ and outdoor occupancy factor (0.2) proposed by UNSCEAR (2008) were used to estimate the annual effective dose rates [1]. The annual effective dose received by population varies between 0.4 to $5.3 \mathrm{mSv} /$ year. The results showed that more than $85 \%$ of the zircon sand samples contribute to the annual effective dose above the limit of $1 \mathrm{mSv} / \mathrm{year}$ and the average annual effective dose $2.1 \mathrm{mSv} /$ year are higher than the permitted value.

However, it is evident that the annual effective dose received by a worker who handles zircon sand is likely to exceed $1 \mathrm{mSv}$ with average $2.1 \mathrm{mSv}$. In such situations, the regulator could decide to impose radiation protection requirements. It is good practice in terms of occupational health and safety (OHS) and environmental protection to identify and implement any simple measures, for example limitation of occupancy periods near accumulations of material, wearing safety work devices (mask, hand gloves etc) and minimization of airborne dust, that may be effective in reducing the radiological impact on workers and members of the public.

\section{CONCLUSION}

The measured radionuclides ${ }^{238} \mathrm{U}$ and ${ }^{232} \mathrm{Th}$ in the zircon sands showed higher radionuclide levels and higher activity concentrations than in soil or iron sand. Radiation exposure of workers in processing and mining of the zircon 
sand is likely to occur at levels above the dose limit for members of the public $(1 \mathrm{mSv} /$ year) and therefore radiation doses should be assessed as occupational exposures. The regulatory body must examine certain work processes to decide on the most appropriate regulatory. In some situations, authorization in the form of registration may be needed to ensure that certain basic control measures are maintained and implemented.

\section{REFERENCES}

1. United Nations Scientific Committee on the Effects of Atomic Radiation (UNSCEAR). Sources and Effects of Ionizing Radiation United Nations Scientific Committee on the Effects of Atomic Radiation UNSCEAR 2008. Vol. I. 2010.

2. Canadian Nuclear Safety Commision. Fact Sheet: Natural Background Radiation. 2013;(January):1-4. Available from: http://nuclearsafety. gc.ca/eng/pdfs/Fact_Sheets/Fact-SheetBackground-Radiation-eng.pdf

3. Joyce PJ, Goronovski A, Tkaczyk $\mathrm{AH}, \mathrm{Björklund} \mathrm{A.} \mathrm{A} \mathrm{framework} \mathrm{for}$ including enhanced exposure to naturally occurring radioactive materials (NORM) in LCA. Int J Life Cycle Assess. 2017;22(7):1078-95.

4. 4. Cooper MB. Naturally Occurring Radioactive Materials ( NORM ) in Australian Industries Review of Current Inventories and Future Generation. 2005.

5. Firestone, Michael, Tulve, Nicholle; Broder, Micheal; Mulford, Eloise;Sheldon, Linda; Stahl, Cynthia;Zartarian V. Guidelines for Human Exposure Assessment Risk Assessment Forum. 2016;
6. IAEA International Atomic Energy Agency. Safety Reports Series no. 51, Radiation Protection and NORM Residue Management in the Zircon and Zirconia Industries. Vienna; 2007. $162 \mathrm{p}$.

7. Sasaki T, Rajib M, Akiyoshi M, Kobayashi T, Takagi I, Fujii T, et al. Laboratory Enrichment of Radioactive Assemblages and Estimation of Thorium and Uranium Radioactivity in Fractions Separated from Placer Sands in Southeast Bangladesh. Nat Resour Res [Internet]. 2015;24(2):209-20. Available from: http://dx.doi.org/10.1007/s11053-0149248-6

8. Sartandel SJ, Bara S V., Chinnaesakki S, Tripathi RM, Puranik VD. Measurement of naturally occurring radioactive materials (NORM) in beach sand minerals using HPGe based gamma-ray spectrometry. J Radioanal Nucl Chem. 2012;294(3):447-51.

9. Olise FS, Oladejo OF, Almeida SM, Owoade OK, Olaniyi HB, Freitas MC. Instrumental neutron activation analyses of uranium and thorium in samples from tin mining and processing sites. J Geochemical Explor. 2014;142:36-42.

10. Olise FS, Owoade OK. Radiological indices of technologically enhanced naturally occurring radionuclides : a PIXE approach. J Radiol Prot. 2011;31:255-64.

11. Glascock M.D. Overview of Neutron Activation Analysis [Internet]. [cited 2019 Feb 11]. Available from: http:// archaeometry.missouri.edu/naa overview.html

12. Mohanty AK, Sengupta D, Das SK, Saha SK. Natural radioactivity and radiation exposure in the high background area at Chhatrapur beach placer deposit of Orissa, India. J Environ Radioact. 2004;75:15-33. 
13. Afifi EM El, Hilal MA, Khalifa SM, Aly HF. Evaluation of $U$, Th, $\mathrm{K}$ and emanated radon in some NORM and TENORM samples. Radiat Meas. 2006;41:627-33.

14. Syarbaini, Setiawan A. Terrestrial Gamma Radiation Exposure in BangkaBelitung Islands, Indonesia. Atom Indones. 2015;41(1):41-5.

15. Papadopoulos A, Koroneos A, Christofides G, Stoulos S. Natural radioactivity distribution and gamma radiation exposure of beach sands close to Kavala pluton, Greece. Open Geosci. 2015;7(1):407-22.

16. Papadopoulos A, Christofides G, Koroneos A, Stoulos S. Natural radioactivity distribution and gamma radiation exposure of beach sands from Sithonia Peninsula. Cent Eur J Geosci. 2014;6(2):229-42.

17. Carvalho FP, Matine OF, Taímo S, Oliveira JM, Silva L, Malta M. Radionuclides and radiation doses in heavy mineral sands and other mining operations inmozambique. Radiat Prot Dosimetry. 2014;158(2):181-6.
18. Righi S, Verità S, Albertazzi A, Rossi PL, Bruzzi L. Natural radioactivity in refractory manufacturing plants and exposure of workers to ionising radiation. J Environ Radioact [Internet]. $2009 ; 100(7): 540-6$. Available from: http://dx.doi.org/10.1016/j. jenvrad.2009.03.008

19. Marocchi M, Righi S, Maria Bargossi G, Gasparotto G. Natural radionuclides content and radiological hazard of commercial ornamental stones: An integrated radiometric and mineralogical-petrographic study. Radiat Meas [Internet]. 2011;46(5):53845. Available from: http://dx.doi. org/10.1016/j.radmeas.2011.03.017

20. Zaman M, Schubert M, Antao S. Elevated radionuclide concentrations in heavy mineral-rich beach sands in the Cox's Bazar region, Bangladesh and related possible radiological effects. Isotopes Environ Health Stud. 2012;48(4):51225. 